УдК 94:327(497.1:493)"1952/1956"

329.14(493)"1952/1956"

329.15(497.1)"1952/1956"

DOI https://doi.org/10.31212/tokovi.2021.3.avm.121-143

Оригинални научни рад

Примљен: 14. 8. 2021.

Прихваћен: 12. 11. 2021.

Aleksandar V. MILETIĆ

Institute for Recent History of Serbia, Belgrade samiletic82@gmail.com

\title{
Yugoslav Communists and Belgian Socialists 1950-1956*
}

ABSTRACT: This paper covers a somewhat forgotten theme in the Yugoslav foreign policy during the Cold War - the relation between Yugoslav Communists and Belgian Socialists in the early 1950s. The research for this topic was carried out mainly on the basis of unpublished archival sources of Yugoslav provenance, as well as adequate academic, historiographical, and other related publications.

KEY WoRDS: Yugoslav Communists, Belgian Socialists, Cold War, Yugoslavia, Belgium

\section{Introduction}

A specific historical situation that Yugoslavia faced in the late 1940s dictated in many ways the creation of specific methods, paths, directions in its foreign policy. The split and political confrontation with its recent role model, patron, and ally, the USSR and Eastern Bloc (1948), suddenly placed Yugoslavia in a very difficult and complex position of an entirely isolated country both from the East and West. ${ }^{1}$ Thus, after all hopes for

* This research was supported by the Science Fund of the Republic of Serbia, PROMIS, \#6062589, YEH.

1 For more on the Yugoslav-Soviet confrontation, see: Владимир Дедијер, Изгубљена битка Јосифа Висарионовича Стаљина, (Сарајево: Свјетлост, Просвета, Ослобођење, 1969); Čedomir Štrbac, Jugoslavija i odnosi između socijalističkih zemalja. Sukob KPJ i Informbiroa, (Beograd: Prosveta, 1984); Čedomir Štrbac, Svedočanstva o 1948, (Beograd: Zavod za udžbenike i nastavna sredstva, 1989); Ivo Banac, Sa Staljinom protiv Tita. Informbirovski rascjepi u jugoslavenskom komunističkom pokretu, (Zagreb: Globus, 1990); Jugoslovensko-sovjetski sukob 1948. Zbornik 
improvement of relations with the USSR and the internationalization of the Yugoslav issue ${ }^{2}$ faded, finding other allies in the world and steering the state course away from the East was being taken into consideration. All arguments pushed the Yugoslav leadership closer to the West.

Intensive cooperation between Socialist Yugoslavia and the west began at the very beginning of the 1950s. That cooperation covered multiple spheres, from political support in international forums, to military and economic aid, to cultural cooperation, which was to develop more and obtain its specific forms. In that sense, in the early years, cooperation was the most intensive in the military and economic sphere. ${ }^{3}$ However, even though the cooperation between Yugoslavia and the West (i.e., the allied bloc led by the USA) could be nothing more than sharing mutual interests (mutual opposition to the USSR and its bloc of countries), ${ }^{4}$ that cooperation undoubtedly led to specific and unpleasant consequences for the Yugoslav leadership. Namely, that cooperation primarily meant serious ideological and political compromise of Yugoslavia as a socialist country before the international labour movement and parties of the left across the world. Thus contacts with the representatives of West Europe-

radova sa naučnog skupa, prir. Đ. Tripković, (Beograd: ISI, 1999); Зборник радова са међународног округлог стола: Тито-Стаљин, прир. М. Милошевић, (Београд: Архив СЦГ, 2007); Milovan Đilas, Vlast i pobuna, (Beograd: Književne novine, 1991), 71-241; Милован Ђилас, Савремене теме, (Београд: Борба, 1950); Милован Ђилас, О агресивном притиску влада совјетског блока против Југославије, (Београд: Борба, 1951).

2 For more on Yugoslav foreign policy after the split with the USSR, see: Jadranka Jovanović, Jugoslavija u Ujedinjenim nacijama 1945-1953, (Beograd: ISI, 1985); Darko Bekić, Jugoslavija u Hladnom ratu. Odnosi s velikim silama 1949-1955, (Zagreb: Globus, 1988); Dragan Bogetić, Koreni jugoslovenskog opredeljenja za nesvrstanost, (Beograd: ISI, 1990); Dragan Bogetić, Nova strategija jugoslovenske spoljne politike 1956-1961, (Beograd: ISI, 2006); Velike sile i male države u hladnom ratu 1945-1955. Slučaj Jugoslavije, prir. Lj. Dimić, (Beograd: Filozofski fakultet, Arhiv SCG, INIS, 2008); Ljubodrag Dimić, Jugoslavija i Hladni rat. Ogledi o spoljnoj politici Josipa Broza Tita (1944-1974), (Beograd: Arhipelag, 2014).

3 See more about the cooperation between Yugoslavia and the West During this period: Dragan Bogetić, Jugoslavija i Zapad 1952-1955. Jugoslovensko približavanje NATO-u, (Beograd: Službeni list SRJ, 2000); Balkanski pakt 1953/1954, prir. dr Milan Terzić, dr Mihajlo Basara, Nemanja Milošević, Miljan Milkić, Dmitar Tasić, Tatjana Lečić, (Beograd: Vojnoistorijski institut, 2005); Ivan Laković, Zapadna vojna pomoć Jugoslaviji 1951-1958, (Podgorica: Istorijski institut Crne Gore, 2006); Александар Животић, Вашингтонска конференција 1951, (Београд: Завод за уџбенике, ИНИС, 2015).

4 Александар В. Милетић, Преломна времена. Милован Ђилас и западноевропска социјалистичка и социјалдемократска левища 1950-1954, (Београд: ИНИС, 2019), 39. 
an socialist and social democratic parties were made in the early 1950s as one of the significant forms of cooperation aimed, among other things, towards mitigating the mentioned political compromise of the Yugoslav leadership and Yugoslavia as the state.

After WWII, Western Europe witnessed a sudden rise of the left, which gained great popularity among the masses after the victory of the anti-fascist coalition. Socialists, social democrats, labourists, even communists formed governments independently or participated in governing coalitions in most Western European countries. That rise would decline in the early 1950s, with the parties of the right and centre and various conservative political options returning to power in most countries. ${ }^{5}$ The first significant contacts with the representatives of the greater part of Western European socialist and social democratic parties began in 1950 when party delegations of European socialists made their first visits to Yugoslavia. ${ }^{6}$ From then until Stalin's death in 1953, possibly one of the most delicate and complex periods in the history of socialist Yugoslavia's foreign policy, Yugoslav Communists established dynamic relations with the British Labour Party, French Socialists, German Social Democrats, Scandinavian Socialists, Swiss Social Democrats and various smaller fractions and individuals from Western socialist circles. ${ }^{7}$ Throughout the story, Belgian

5 See more about the rise and actions of the left in the Westafter WWII: Stephen Padgett, William E. Paterson, A History of Social Democracy in Postwar Europe, (New York: Longman, 1991); Geoff Eley, Forging Democracy. The History of the Left in Europe, 1850-2000, (New York: Oxford University Press, 2002); David Childs, The Two Red Flags. European Social Democracy and Soviet Communism since 1945, (London - New York: Routledge, 2002); Volter Laker, Istorija Evrope 1945-1992, (Beograd: CLIO 1999); Donald Sassoon, One Hundred Years of Socialism. The West European Left in the Twentieth Century, (London - New York: I. B. Tauris, 2010); Talbot C. Imlay, The Practice of Socialist Internationalism. European Socialists and International Politics, 1914-1960, (Oxford: Oxford University Press, 2018).

6 Seе: Александар В. Милетић, „Пријем делегације британских лабуриста код маршала Тита у оквиру њихове прве посете Југославији, 1950. године“. Токови uсторuje 1/2011, 137-164; Čedomir Štrbac, „Britanski laburisti u Jugoslaviji 1950“, Međunarodni problemi 4/1987, 543-551; Vladimir Dedijer, Veliki buntovnik Milovan Đilas. Prilozi za biografiju, (Beograd: Prosveta, 1991), 371-382.

7 See more about these relations: Arhiv Jugoslavije (AJ), Fond 142, Socijalistički savez radnog naroda Jugoslavije (SSRNJ), Materijal o saradnji SSRNJ sa socijalističkim partijama i progresivnim pokretima. Socijalističke partije Zapada; Александар В. Милетић, „Милован Ђилас и француски социјалисти 1950-1954“, Токови uсторије 1/2020, 155-174; Aleksandar V. Miletić, 'Unrelized Nordic Dream'. Milovan Đilas and the Scandinavian Socialists", Токови историје 3/2015, 89-104; Natalija Dimić, "In Search of an Authentic Position: The First Phase of Political and Ideological Cooperation between Yugoslavia and West European Left, 1948-1953", Acta Histriae 1/2019, 55-74; Aleksandar V. Miletić, "The Relationships between 
Socialists had an essential position as a party strongly in favour of Yugoslavia and its politics at the time. ${ }^{8}$

\section{The Period of Foreign Policy Crisis}

Yugoslav-Belgian relations after WWII were at an acceptable level of two relatively geostrategically distant countries, which, on the one hand, belonged to different political and ideological blocs, but at the same time, did not have any immediate reasons for mutual antagonism. Unlike Yugoslavia, the Kingdom of Belgium continued to be a classic Western parliamentary democracy, with a capitalist social and economic system and political pluralism. ${ }^{9}$ After the war, the Socialists came to power and they participated in various coalition governments until 1949, when they were replaced by Christian Socialists, as a new dominant force in Belgian political life. ${ }^{10}$ The Socialists regained power in April 1954, when they formed a coalition government with the Liberals.

cialist Party (Parti Socialiste helge/Belgische Socialistische Partii- PSB/ $\mathrm{BSP})^{11}$ started at the very beginning of the $1950 \mathrm{~s}$, when some respecta-

Yugoslav Communists and Scandinavian Socialists in the Light of Yugoslav Sources (1950-1953)", Acta Histriae 1/2019, 75-87.

8 Affinity of Belgian Socialists for Yugoslavia was shown in many cases, especially before the creation of the Socialist International, in the summer of 1951, when, due to their attitude they confronted some Western socialist parties, such as the Dutch party. The Dutch party, unlike the Belgian, had a very negative attitude towards Yugoslavia. Thus, we learned from one document that the representatives of the Belgian Socialists considered the Dutch Socialists to be the "rightmost" party within the Socialist International and that they considered them Socialists "only in form", but not in politics. They also openly announced this to the representatives of the Yugoslav communists. See: Arhiv Jugoslavije (AJ), Fond 507/IX, CK SKJ, Komisija za međunarodne odnose i veze (KMOV), Belgija, 11/II-9, Zabeleška o razgovoru sa Piot Ernestom, generalnim sekretarom Socijalističke partije Belgije, održan 5. jula 1951.

9 Belgium emerged from WWII without any major damage, so it was able to renew its political, social, economic, and cultural life without hindrance. Already during the war, it made a customs union with its immediate neighbours, the Netherlands and Luxembourg, which would function under the name Benelux from 1947. As a reliable political part of the Western world, Belgium joined the newly formed Atlantic Pact (NATO) in 1949.

10 See: Peter Van Kemseke, Towards an Era of Development. The Globalization of Socialism and Christian Democracy 1945-1965, (Leuven: Leuven University Press, 2006).

11 See more about the politics of the Belgian Socialist Party in this period: Diplomatski arhiv Ministarstva spoljnih poslova Republike Srbije (DAMSPRS), Politička arhiva 
ble representatives of Belgian Socialists paid a visit to Yugoslavia. One of them was Paul Speyer, a young lawyer, who came to Yugoslavia on a private visit in September 1950. Having returned home, he wrote enthusiastically about this country, fairly unknown to the Belgians: "Yugoslavia is the only perspective for the international labour movement. I will not diverge from that standpoint." ${ }^{12}$ In September the following year, a moderate but basically positive report on Yugoslavia was delivered by two Belgian Socialists, Léo Collard ${ }^{13}$ and William Van Remoortel, ${ }^{14}$ who understood to some extent the Yugoslav political system and its foreign policy. ${ }^{15}$ Victor Larock ${ }^{16}$ one of the most influential persons among Belgian and European socialists and the actual president of COMISCO, ${ }^{17}$ also had

(PA), 1950, Belgija, f. 9, br. 423366, Izveštaj o Kongresu PSB, 12.12.1950; DAMSPRS, PA, 1952, Belgija, f. 9, br. 44889, Izveštaj o Kongresu PSB, 5. 4. 1952; DAMSPRS, PA, 1952, Belgija, f. 9, br. 48199, Telegram MIP-u (PSB-spoljna politika), 17. 6. 1952; DAMSPRS, PA, 1954, Belgija, f. 9, br. 416459, Telegram SIP-u. Utisci o Kongresu PSB, 14. 12. 1954; DAMSPRS, PA, 1955, Belgija, f. 6, br. 47223, Politički izveštaj od 23. 5. 1955; DAMSPRS, PA, 1955, Belgija, f. 6, br. 47223, Politički izveštaj od 24. 10. 1955; DAMSPRS, PA, 1956, Belgija, f. 7, br. 4596, Godišnji izveštaj SIP-u, 16. 1. 1956.

12 AJ, 507/IX, СК SKJ, KMOV, Belgija, 11/II-1, Biografija Pola Spajera; Милетић, Преломна времена, 187.

13 Léo Collard (1902-1981), Belgian socialist politician and a lawyer. He was born to the middle-class family, got a PhD in law in Brussels. A socialist by choice, he joined the Belgian Labour Party during his studies and became its councillor in the City of Mons. After the war, he joined the freshly formed Belgian Socialist Party (PSB/ BSP) and was elected Minister of Education (1946). He was in charge of the same department in the governments to come (1954-1958). For many years, he remained a mayor of the City of Mons (1953-1974). He died in Mons in 1981.

14 William Van Remoortel (1888-1965), Belgian socialist politician and senator. With a $\mathrm{PhD}$ in law, he was a lawyer by profession. He volunteered in WWI. Between the two wars, he was a member of the Belgian Labour Party. After WWII, he joined the Belgian Socialist Party (PSB/BSP). A Member of the Belgian Senate (1937-1961). He left the PSB in 1961. He died in Brussels in 1965.

15 See: DAMSPRS, PA, 1951, Belgija, f. 9, br. 49975, Zabeleška o razgovoru savetnika Nikolajevića sa socijalističkim senatorom William Van Remoortel-om, 21. 6. 1951; DAMSPRS, PA, 1951, Belgija, f. 9, br. 411685, Telegram MIP-u, 14. 8. 1951; AJ, 507/ IX, CK SKJ, KMOV, Belgija, 11/II-11, Zabeleška o razgovoru Milovana Đilasa sa Leom Kolarom, članom Biroa SP Belgije i Van Remortelom, socijalističkim senatorom, 13. septembra 1951.

16 Victor Larock, (1904-1977), Belgian Socialist, a philosopher by education. During WWII, he participated in the Belgian Resistance Movement. After the war, he was an editor of the socialist newspaper Le Peuple and a member of the Belgian Parliament. He was Minister of Foreign Trade (1954-1957), Minister of Foreign Affairs (19571958), President of COMISCO and one of the advocates of the creation of the Socialist International.

17 Committee of the International Conference of Socialists (Spanish: Comité de la Conferencia Socialista Internacional - COMISCO), was an international forum of socialist 
a positive attitude towards Yugoslavia at the time. This Belgian socialist maintained regular contact with the Yugoslav party and diplomatic representatives and attempted to use his authority and influence to support Yugoslav politics among European and Belgian socialists. ${ }^{18}$ In a conversation with the Yugoslav diplomatic representative in Belgium, Socialist MP Léo Collard openly stated that socialism in Yugoslavia was a valuable experience for Belgian Socialists and that "after England, where the implementation of socialism ceased, Yugoslavia is today the only country in the world which is pursuing socialism." ${ }^{19}$ Similar attitudes were shared by Joseph Bracops, ${ }^{20}$ president of one of the Brussels municipalities (Anderlecht), who visited the capital of Yugoslavia in October 1951 and met with Josip Broz Tito. ${ }^{21}$ In this period, individuals from the circles of Belgian Socialists publicly supported Yugoslavia, spoke positively about the

parties and movements that existed from 1947 to 1951. From this organization, the Socialist International was formed in July 1951, which was a continuity of the prewar Labour and Socialist International.

18 The extent to which this high-ranking official of the Belgian Party trusted the Yugoslavs is seen in a report by Yugoslav envoy Latinović on his meeting with Victor Larock in early March 1951. Larock then briefed Latinović in detail on the COMISCO meeting at which the future Socialist International was discussed and the positions of the European Socialists on Yugoslavia. Larock then asked the Yugoslav envoy to burn the note of their meeting, so it would not reach the public and cause damage, given the position and standing that Victor Larock enjoyed in political circles at the time. See: AJ, 507/IX, CK SKJ, KMOV, Belgija, 11/II-7, Zabeleška o razgovoru L. Latinovića sa Viktorom Larokom, mart 1951; AJ, 507/IX, CK SKJ, KMOV, Belgija, 11/II-3, Zabeleška o razgovoru L. Latinovića, poslanika FNRJ u Belgiji, sa Viktorom Larokom, 27. februara 1951; AJ, 507/IX, CK SKJ, KMOV, Belgija, 11/II-7, Zabeleška o razgovoru L. Latinovića, poslanika FNRJ u Belgiji, sa Viktorom Larokom, sekretarom SP Belgije.

19 AJ, 507/IX, CK SKJ, KMOV, Belgija, 11/II-15, Zabeleška o razgovoru R. Nikolajevića sa Leo Collardom, socijalističkim narodnim poslanikom, 22. januara 1952.

20 Joseph Bracops (1900-1966), a Belgian communist and socialist politician. He was a teacher by profession. From 1920 until WWII, he lived in Anderlecht (Brussels region), and worked as a primary school teacher. He was one of the founders of the Communist Party of Belgium, but after visiting the USSR he left the Communists and became a Socialist. After WWII, he became a mayor of Anderlecht (1947-1966) and a member of the Belgian Parliament (1946-1966).

21 See: AJ, 507/IX, CK SKJ, KMOV, Belgija, 11/II-4, Zabeleška o razgovoru sa Žoze Brakoom, članom Politbiroa SP Belgije, 8. marta 1951; AJ, 507/IX, CK SKJ, KMOV, Belgija, 11/II-12, Poseta Žoze Brakoa, člana Politbiroa SP Belgije, Jugoslaviji oktobra 1951; Милетић, Преломна времена, 191-192. 
country, most frequently via public lectures, ${ }^{22}$ or sent positive messages and initiatives for the cooperation with the Yugoslav Party. ${ }^{23}$

These and other similar activities of individuals from the circles of Belgian Socialists greatly contributed to Yugoslavia breaking through the political blockade in the world. ${ }^{24}$ However, the cooperation with the PSB officially started in mid-1952, when high-level delegates from the Belgian Party visited Yugoslavia. The visit was organized at the initiative of Yugoslavia. Every visit and stay of a delegation of any socialist party, and therefore the Belgian, was of great importance to the Yugoslav leadership as it eliminated prejudice against the restrictedness, rigidity, and political exclusivity of the Yugoslav system. Thus, the high-level delegation of the Belgian Socialist Party, headed by its president Max Buset, ${ }^{25}$ visited Yugoslavia from July 29 to August 21952 and, on that occasion, met with high-ranking Yugoslav officials, including Josip Broz Tito. ${ }^{26}$ This visit of the Belgian Socialists to Yugoslavia indicated good cooperation and mutual affinity.

22 See:AJ, 507/IX, СК SКJ, KMOV, Belgija, 11/II-15,Zabeleška o razgovoru R. Nikolajevića sa Leo Collardom, socijalističkim narodnim poslanikom, 22. januara 1952; AJ, 507/IX, CK SKJ, KMOV, Belgija, 11/II-16, Zabeleška o razgovoru Bernardić Dragana Bracops Josephom, članom Politbiroa SP Belgije, 29. januara 1952.

23 See: DAMSPRS, PA, 1951, Belgija, f. 9, br. 413482, Zabeleška o razgovoru sa Arthur Gailyy-em, poslanikom PSB, 21. 8. 1951; DAMSPRS, PA, 1951, Belgija, f. 9, br. 413482, Zabeleška o razgovoru sa Ernest Piot-om, generalnim sekretarom PSB, 7. 9. 1951; DAMSPRS, PA, 1951, Belgija, f. 9, br. 42435, Telegram Aleša Beblera MIP-u, New York, 20.2.1951.

24 For example, this was especially evident in the attitudes of the Belgian socialists regarding the Yugoslav membership in the Socialist International, an important and influential international organization of socialist and social democratic parties founded at that time (in the summer of 1951). For understandable reasons, Yugoslavia needed the presence of as many organizations and forums in the world as possible, so in that respect, Belgian socialist Victor Larock, then president of COMISCO, the organization from which the Socialist International emerged, was in a very good position to lobby for Yugoslav communists, which he did, but without much success.

25 Max Buset (1896-1959), a Belgian socialist politician. Before WWII, he was a member of the Belgian Labour Party. He was a member of the Belgian Parliament (1932-1952) and the first president of the Socialist Party of Belgium (1945-1959). Under his leadership, the Belgian Socialists played an important role in the removal of King Léopold III of Belgium in 1951.

26 The structure of the Belgian Socialists delegation was at a very high level, so besides President Max Buset, it also included prominent figures such as Victor Larock, François Tielemans, Jos Van Eynde, Auguste de Block, Ernest Piot. During the visit, the Belgian guests, in addition to meeting and talking with high-ranking Yugoslav officials, had the opportunity to travel around Yugoslavia and visit its largest cities and political, cultural and economic centres. See: AJ, 507/IX, CK SKJ, KMOV, Belgija, 11/II-19, Razgovor Josipa Broza Tita sa delegacijom belgijskih socijalista, 30. jula 1952; Милетић, Преломна времена, 194-196. 
All similarities and discrepancies could be seen in the discussion the Belgian delegates had with Josip Broz Tito on July 30, 1952. For instance, the Belgians were primarily interested in the Yugoslav attitude towards the USSR and the Cold War, given its specific position and hostile view of the Western political circles on Moscow, shared to some extent by the Belgian Socialists as well. Namely, Western politicians at the time were worried the USSR might attack Western Europe, so Belgian Socialists wanted to know what the Yugoslav leader thought about that. Tito answered his Belgian guests' question composedly and serenely, but he was also very clear and dispassionate: there was no easing of pressure from the USSR towards the West, but Yugoslavs believed there was no immediate danger of an attack. "It is all part of the Cold War, which the Russians will prolong, but there is no immediate danger of war," Tito said on that occasion. ${ }^{27}$ With this, Tito primarily wanted to show determination and sobriety in understanding the Cold War relations, i.e., that he was aware of the gravity of the situation and the danger threatening from the East, but also the "realpolitik" of Yugoslavia regarding such circumstances. ${ }^{28}$ In this regard, he expressed his view that Yugoslavia should also be armed, but only to the extent necessary for its own defence, which the Belgians understood well. ${ }^{29}$ Regarding the idea of collective defence of the West from a Soviet attack, primarily via NATO, Tito clearly stated that Yugoslavia did not intend to join any alliance of such kind; rather, it would associate its policy exclusively to the UN institutions. However, in the case of a Soviet attack on Europe, Yugoslavia would support Europe. ${ }^{30}$

Another significant issue on which the Belgian Socialists agreed with the Yugoslav Communists was the development of socialism. Namely, the Belgian guests were impressed by Tito's and the Yugoslav leaders' attitude towards the independent path to socialism as a right which every country should have. Tito pointed out that Yugoslavia abandoned the Soviet approach to the development of socialism and decided to take their own path, which did not imply that they would entirely accept the per-

27 AJ, 507/IX, CK SKJ, KMOV, Belgija, 11/II-19, Razgovor Josipa Broza Tita sa delegaciojom belgijskih socijalista, 30. jula 1952,1-2.

28 Tito also had such a moderate attitude regarding the current problem of Germany's potential arming in defense against the USSR, saying that Germany should undoubtedly arm itself, but only to defend itself. Ibid., 2-3.

29 Ibid., 4.

30 Ibid., 4-5. 
spectives of other socialist movements in the world, which Belgians completely agreed with. ${ }^{31}$

The attitude of Belgian Socialists towards Yugoslav Communists was therefore friendly and positive, but to a certain extent also restrained and cautious. Thus, for example, Belgian Socialists, despite all affinities for the Yugoslav foreign policy and to some extent for Yugoslav ideological positions, did not consider it necessary to send a delegation to the founding congress of the Socialist Alliance of the Working People of Yugoslavia (SSRNJ) in February 1953. ${ }^{32}$ Also, Belgian Socialists, regardless of their support for the Yugoslav leadership, were visibly tactful regarding the membership of the Yugoslav Party in the Socialist International. Lastly, whatever sympathies they had for the social order and political system of Yugoslavia, Belgian Socialists remained critical of the "one-party dictatorship" and the absence of democratic pluralism in Yugoslav internal political life. ${ }^{33}$

\section{In the Era of Foreign Policy Stabilization}

A significant event that shook the Yugoslav party and leadership in early 1954 was the deposition of Milovan Đilas, one of the highest Yugoslav officials, due to political disagreements with the rest of the leadership. ${ }^{34}$ Most socialist parties in Western Europe were shaken and accepted the news with disbelief, given that Milovan Đilas was a vital individual in the Yugoslav party leadership directly in charge of establishing relations and developing cooperation with Western parties. However, to a greater or lesser extent, all Western European socialist parties still agreed to the official attitude of the Yugoslav leadership towards the "Đilas case" with loud protests from some individuals, so that this event did not significantly affect further cooperation. ${ }^{35}$ It was similar with Belgian Socialists, so the Yugoslav party representatives who paid visits to Western European

31 Ibid., 6-7. Also see: AJ, 507/IX, CK SKJ, KMOV, Belgija, 11/II-19, Pismo predsednika PSB Max Buset-a Centralnom komitetu KPJ, 14. avgust 1952.

32 The party documents indicate that the absence the PSB delegation at the Popular Front Congress in 1953 was perceived by Yugoslavia as a noticeable "stain" in the otherwise positive relations between the two parties. See: AJ, 507/IX, CK SKJ, KMOV, Belgija, 11/II-33, Informacija o odnosima sa SP Belgije, 1954.

33 Милетић, Преломна времена, 189-190.

34 See more: Александар В. Милетић, „Политичка делатност Милована Ђиласа (1944-1954)“, (докторска дисертација, Универзитет у Београду, Филозофски факултет, Одељење за историју, 2017), 654-790.

35 Seе: Милетић, Преломна времена, 225-252. 
parties after Đilas's deposition had the impression that this event did not leave any effect on the PSB leadership. ${ }^{36}$

Thus, the cooperation with the PSB remained unhindered during the following years. In 1954, the most important event for Belgian Socialists was certainly the formation of a coalition government in April, and for the Yugoslav side, the visit of the SSRNJ delegation to Belgium in September and October. ${ }^{37}$ The SSRNJ delegation visited the PSB in the period of September 26 to October 6, 1954. On that occasion, they met with numerous figures from the circles of the Belgian Socialists, the state apparatus, trade unions, and Belgian political life. ${ }^{38}$ The SSRNJ delegation was led by Edvard Kardelj, Vladimir Bakarić and Rodoljub Čolaković. The Yugoslavs had the opportunity to get acquainted with the activity of the Belgian party, its organization and functioning, and the role of institutions in social life. Having returned, the Federal People's Republic of Yugoslavia delegates concluded that Belgian Socialists cultivated friendly relations with Yugoslavia, that they had full understanding for the Yugoslav independent development of socialism, and that they showed great interest in Yugoslav construction and labour management, seeking experience for their own development. It was also noticed that Belgian Socialists showed great interest in more active cooperation with the Yugoslav Party, not hiding and openly showing their affinities for Yugoslavia before their public. ${ }^{39}$ During the Yugoslav delegation's visit, the Secretary-General of the PSB, Er-

36 See: AJ, 507/IX, СK SKJ, KMOV, Belgija, 11/II-26, Informacija o putu druga Veljka Vlahovića u zapadno evropske zemlje, 25. 2. - 6. 3. 1954.

37 See: AJ, 507/IX, CK SKJ, KMOV, Belgija, 11/II-31, Delegacija SSRNJ u poseti Belgiji od 26. septembra do 6. oktobra 1954. godine; DAMSPRS, PA, 1954, Belgija, f. 9, br. 413288, Telegram SIP-u od 11. 6. 1954; DAMSPRS, PA, 1954, Belgija, f. 9, br. 413288, Telegram SIP-u od 8. 10.1954.

38 See: AJ, 507/IX, СК SKJ, KMOV, Belgija, 11/II-31, Boravak delegacije SSRNJ u Belgiji; AJ, 507/IX, CK SKJ, KMOV, Belgija, 11/II-31, Zabeleška sa ručka kod ministra spoljne trgovine Victor Larock-a, 28. 9. 1954; AJ, 507/IX, CK SKJ, KMOV, Belgija, 11/II-31, Sastanak sa Pyot-om, održan 28. 9. 1954. Izlaganje o organizaciji i radu PSB; AJ, 507/ IX, CK SKJ, KMOV, Belgija, 11/II-31, Sastanak sa Biroom Socijalističke partije Belgije, održan 29. septembra 1954; AJ, 507/IX, CK SKJ, KMOV, Belgija, 11/II-31, Razgovor sa ministrom rada Trocklet-om, 30. septembra 1954; AJ, 507/IX, CK SKJ, KMOV, Belgija, 11/II-31, Sastanak u Birou PSB 6. oktobra 1954.

39 AJ, 507/IX, CK SKJ, KMOV, Belgija, 11/II-31, Stenografske beleške sa sastanka Komisije za međunarodne veze SSRNJ, održanog 16. 10. 1954, povodom povratka delegacije SSRNJ sa posete Socijalističkoj partiji Belgije. 
nest Piot, ${ }^{40}$ made it clear that the Belgian Party was publicly backing Yugoslavia's struggle for independence. ${ }^{41}$

It seemed that the visit of the SSRNJ delegation to Belgium particularly influenced the Yugoslav Communists' determination to deepen and improve relations not only with the PSB but also with other socialist parties in Western Europe. Therefore, Veljko Vlahović, the head of the Foreign Policy Commission of the SSRNJ, wrote in a letter to the Yugoslav diplomatic representative in Belgium that following the visit of the SSRNJ delegation to Belgium, the cooperation with Western Socialists should be further strengthened and that, at the time, the Commission clearly noticed the importance of connecting with "prominent individuals from the socialist parties," as well as the significance of getting acquainted with the wider infrastructures of the parties there. "The Commission," Vlahović stated, "adopted the standpoint that our future connections and contacts should not be limited to connections and cooperation only with the leaders in some, but they should also be oriented more to depth, to seeking connections and cooperation with party organizations on the ground and mid-level party officials... After all, our cooperation with the Belgian Socialist Party and the trade unions has been developing in that direction." ${ }^{42}$

Thus, based on the experience of the Yugoslav delegation, as well as Veljko Vlahović's recommendation and instructions, preparations for the arrival of a PSB party group in Yugoslavia began in the following months. ${ }^{43}$ In May 1955, it was arranged that a 25-member delegation of local (regional) PSB secretaries visit Yugoslavia. ${ }^{44}$ According to the itinerary, the PSB delegation was supposed to visit the most important cities of Yugoslavia - Belgrade, Zagreb, and Ljubljana, as well as Slavonski Brod. PSB secretaries were to meet with local party and local SSRNJ representatives, get acquainted with the infrastructure of the party and mass organizations

40 Ernest Piot (1890-1969), a Belgian socialist politician and senator. Between the two world wars, closer to leftist circles, he joined the Belgian Labour Party. He was secretary general of the Belgian Labour Party and later the Belgian Socialist Party (PSB / BSP) from 1937 to 1954. He was also the city councillor of the City of Hoei (1946-1952), as well as the senator of the province of Liége (1954-1958) and the district of Hoei-Borgworm (1958-1959). He died in Hoei in 1969.

41 AJ, 507/IX, CK SKJ, KMOV, Belgija, 11/II-31, Sastanak sa Pyot-om, održan 28. 9. 1954.

42 AJ, 507/IX, CK SKJ, KMOV, Belgija, 11/II-35, Pismo Veljka Vlahovića, upućeno Barišiću, poslaniku FNRJ u Belgiji, o pitanjima dalje saradnje sa SP Belgije, 31.1.1955.

43 AJ, 507/IX, CK SKJ, KMOV, Belgija, 11/II-39, Pismo Spoljno-političkoj komisiji SSRNJ, Brisel, 25. 4. 1955.

44 AJ, 507/IX, CK SKJ, KMOV, Belgija, 11/II-39, Pismo Marije Vilfan jugoslovenskom poslaniku Barišiću, 19. 5. 1955. 
in Yugoslavia and their way of working. It was also planned for Belgians to visit specific cooperatives, social organizations, and local representatives and factories and thus gain insight into their working system in Yugoslavia. ${ }^{45}$ This visit was realized from September $20^{\text {th }}$ to $30^{\text {th }} 1955$, and the group of regional PSB secretaries consisted of 22 representatives. Due to the lack of time, the visit was limited to the People's Republic of Croatia, ${ }^{46}$ and according to reports, it had very positive results, ${ }^{47}$ as well as a good response in Belgium. The Belgians in return extended an invitation for a similar Yugoslav delegation to visit Belgium. ${ }^{48}$

As part of the intensive cooperation between Yugoslav Communists and Belgian Socialists in this period, we should highlight the activity of the PSB representatives among various socialist parties in Western Europe, before which they often defended and, to some extent, advocated the Yugoslav Party's politics. Thus, in the spring of 1955, at the request of Yugoslav diplomatic representatives in Belgium, the Belgian party launched an initiative to organize a meeting of West European socialists at the Émile Vandervelde Institute in Brussels. ${ }^{49}$ The Belgian side was expected to submit the main report on the current political situation to the Yugoslav representatives, and the Belgian Socialists then used the July session of the Socialist International in London to inform other SI members and present a proposal for Yugoslav participation..$^{50}$ Since all major European social parties, such as British, French, German, and Swiss, accepted the proposal (the Dutch party initially refused to participate due to the presence of Yugoslavs), ${ }^{51}$ the Belgian party undertook to organise the meeting, which was eventually scheduled for November 5 and 6, 1955. The Yugoslav party received an official invitation from the Institute on September 29 via its diplomatic mission in Brussels. According to Yugoslav diplomatic reports,

45 АJ, 507/IX, СК SKJ, KMOV, Belgija, 11/II-39, Plan boravka delegacije PSB-a.

46 AJ, 507/IX, CK SKJ, KMOV, Belgija, 11/II-39, Pismo Spoljnopolitičke komisije SSRNJ jugoslovenskom poslanstvu u Belgiji, 27.10.1955.

47 AJ, 507/IX, CK SKJ, KMOV, Belgija, 11/II-39, Izveštaj o boravku grupe od 22 oblasna sekretara Belgijske socijalističke Partije od 20. do 30. 9.1955.

48 AJ, 507/IX, CK SKJ, KMOV, Belgija, 11/II-39, Izveštaj Ambasade FNRJ u Briselu Komisiji za veze sa inostranstvom SSRNJ o boravku delegacije PSB-a u Jugoslaviji.

49 AJ, 507/IX, CK SKJ, KMOV, Belgija, 11/II-38, Pismo Komisiji za veze sa inostranstvom SSRNJ, Brisel, 22. 7. 1955; AJ, 507/IX, CK SKJ, KMOV, Belgija, 11/II-38, Pismo Ambasade FNRJ u Briselu Komisiji za veze sa inostranstvom SSRNJ, 24. 9. 1955.

50 DAMSPRS, PA, 1955, Belgija, f. 6, br. 410123, Izveštaj Komisijizaveze sainostranstvom SSRNJ, 22.7. 1955.

51 AJ, 507/IX, CK SKJ, KMOV, Belgija, 11/II-38, Pismo Komisiji za veze sa inostranstvom SSRNJ, Brisel, 22. 7.1955. 
the Belgian party showed a strong interest for the event. ${ }^{52}$ In addition to the SSNRJ representatives, the invitations were also sent to the French, British, Dutch, Luxembourg, German, Italian, Swiss, Danish, Swedish, Norwegian, Austrian, and Finnish parties. ${ }^{53}$ However, the Yugoslav diplomatic mission in Belgium was eventually informed at the end of October that, due to misunderstandings and disagreements of certain socialist parties, the gathering of European socialists would not be held at the Vandervelde Institute. Namely, as Brussels explained, the misunderstanding stemmed from the fear of some parties (British, German, Swiss, Austrian, Dutch, and Swedish) that the gathering would lead towards the liquidation of the Socialist International. Such a thought occurred to them because of an article by Veljko Vlahović, published in The Communist (Komunist), whose affirmation of independent political development was too strong. ${ }^{54}$

Yet, it did not prevent the SSRNJ delegates from visiting Belgium in early November. Thus, Veljko Vlahović, the head of the SSRNJ delegation, presented a paper in Brussels on the topic "Development of democracy on the basis of socialist economic relations." ${ }^{55}$ On that occasion, Vlahović, among other things, highlighted the issues of building socialist democracy in Yugoslavia, emphasizing the differences between controlled and directed processes and chaotic development. He did this on the example of the "Đilas case," where there was a showdown between ideologically correct and politically appropriate attitudes and Đilas's anarchist tendencies that were not in accordance with the Yugoslav reality. ${ }^{56}$ The representatives of the Federal People's Republic of Yugoslavia also used their trip to Belgium for a special meeting and exchange of opinions with the Belgian Socialist Party representatives. ${ }^{57}$ The meeting was held on November 3 in Brussels, and the Belgian party was represented by its most influential leaders - President Max Buset, Victor Larock, and Paul-Henri Spaak, then Minister of Foreign Affairs of Belgium. The topics discussed were related to the current international situation, rapprochement between the

52 DAMSPRS, PA , 1955, Belgija, f. 6, br. 414192, Izveštaj SIP-u od 26. 9. 1955.

53 AJ, 507/IX, CK SKJ, KMOV, Belgija, 11/II-38, Pismo R. Evalenka, direktora Instituta Vandervelde poslaniku FNRJ u Briselu, 29. 9.1955.

54 DAMSPRS, PA, 1955, Belgija, f. 6, br. 414192, Izveštaj SIP-u od 20. 10. 1955; Nikola Mijatov, Milovan Đilas i evropski socijalisti 1950-1958, (Beograd: ISI, 2019), 134-137.

55 AJ, 507/IX, CK SKJ, KMOV, Belgija, 11/II-38, Predavanje druga Veljka Vlahovića u Belgiji.

56 Ibid., 4-6.

57 See: AJ, 507/IX, СК SKJ, KMOV, Belgija, 11/II-38, Diskusija između predstavnika SSRNJ i Socijalističke partije Belgije, Brisel, 3. novembra 1955. 
East and West, relations between the Eastern and Western labour movements, impressions that the Yugoslavs had after their visits to the Scandinavian countries ${ }^{58}$ and future cooperation between the SSRNJ and the Belgian Socialist Party.

As reported by the Yugoslav embassy, the discussions between the SSRNJ representatives and the Belgian party certainly affected the attitudes of the PSB leadership. Thus, according to those impressions, the PSB president elaborated on his views on the new foreign policy resolution draft for the upcoming party congress ${ }^{59}$ "on the basis of the discussion with the representatives of the SSRNJ." According to the embassy's report, the PSB president, Max Buset, "continually stressed that these are the experiences of a friendly party that is familiar with both blocs far better than they are and whose assessments can be relied upon confidently." In that sense, the Belgians trusted the Yugoslav assessment of the situation in the USSR, the Eastern countries, and China, as well as the need for cooperation with those countries. Thus, the embassy assessed that President Max Buset fully approves of the Yugoslav foreign policy concept and that he attempted to "engage the PSB leadership in that area as well." The discussions left a particular impression on Paul-Henri Spaak, ${ }^{60}$ the Belgian Minister of Foreign Affairs, who stated that such discussions should

58 Prior to their arrival in Belgium, the SSRNJ delegates visited the Scandinavian countries and the socialist parties there. See: AJ, 507/IX, CK SKJ, KMOV, Belgija, 11/ II-38, Pismo Veljka Vlahovića jugoslovenskoj ambasadi u Briselu, 28. 9.1955.

59 This was the XI Congress of the PSB, held on November 19-20,1955, at which special attention was paid to foreign policy issues. According to the Yugoslav embassy assessments, the anti-colonial line came to the foreground at the Congress, as well as the positive attitude about general disarmament (which gave way to the attitude towards the potential dissolution of NATO) and the need for recognition of the Public Republic of China. The Yugoslav embassy evaluated that in the socialist ranks, this congress is perceived as one of the most successful and most principled, and that its basic feature is a strong tendency towards an independent foreign policy. See: AJ, 507/IX, СК SKJ, KMOV, Belgija, 11/II-40, Jedanaesti kongres SP Belgije, od 19. do 20. novembra 1955.

60 Paul-Henri Spaak (1899-1972), a Belgian socialist politician and statesman. He was born into a prominent Spaak family. A lawyer by profession, he was a German prisoner of war in WWI. After the war, he joined the Belgian Labour Party. At the end of the 1930s, he entered the government and got the transport department, then soon became Prime Minister (1938-1939). He served as Minister of Foreign Affairs (1936-1940). After the war, as a member of the PSB, he was Prime Minister on two occasions (1946 and 1947-1949). He was also President of the UN General Assembly (1946-1947), President of the European Parliament (1952-1954), Minister of Foreign Affairs (1954-1958) and Secretary General of NATO (1957-1961). He died in Braine-l'Alleud in 1972. 
be "systematically continued" because they were very useful to both sides, so the Belgians "sincerely" accepted an invitation to organize a broader discussion in Yugoslavia the following year. ${ }^{61}$

Hence, the crucial event for the relations with the Belgian Socialists in the following year, 1956, was the official visit of the PSB delegation to Yugoslavia. The delegation was headed by the party president Max $\mathrm{Bu}-$ set, and took place from April 10 to April 15, 1956. ${ }^{62}$ The Minister of Foreign Affairs Paul-Henri Spaak was also a member of the delegation. Josip Broz Tito received the delegates on April 13, ${ }^{63}$ and the discussions tackled the topics such as the USSR politics, European cooperation, and the cooperation between the socialist parties. This visit confirmed the favourable cooperation between the two sides, indicating further international support of Belgian Socialists for Yugoslav Communists.

The current topics regarding foreign policy, particularly the socalled "new course" the USSR took after Stalin's death and the XX Congress of the CPSU dominated the discussions with the PSB delegates in April 1956. The fundamental approach of the Yugoslavs, stated by Edward Kardelj, was that the USSR was facing major changes which had "historical revolutionary significance." Those changes were undertaken on the wave of the anti-bureaucratic reform and dismantling of Stalin's personality cult, which was once predicted in Yugoslavia, so that in the USSR "a new Stalin is not possible." ${ }^{64}$ As Kardelj put it, the anticipated changes in the USSR would be in the field of "ideological liberation," "internal democratization," and foreign policy adaptation, and it would be vital to support those positive processes in the international labour movement. For that reason, Kardelj said, it was important to "comprehensively strengthen contacts with the USSR in order to contribute to a faster exchange of opinions between the East and the socialist movements." 65

On this occasion, the Yugoslav party showed a clear tendency towards political balance in international relations by formulating its opinion and approaches cautiously and restrainedly before Belgian Socialists.

61 AJ, 507/IX, CK SKJ, KMOV, Belgija, 11/II-38, Pismo savetnika ambasade FNRJ S. Obradovića Spoljnopolitičkoj komisiji SSRNJ.

62 See: AJ, 507/IX, СК SKJ, KMOV, Belgija, 11/II-44, Delegacija SP Belgije u poseti Jugoslaviji od 10. do 15. aprila 1956.

63 See: AJ, 507/IX, СК SKJ, KMOV, Belgija, 11/II-44, Zabeleška o razgovoru druga Tita sa delegacijom Socijalističke partije Belgije, Brioni, 13. april 1956.

64 AJ, 507/IX, CK SKJ, KMOV, Belgija, 11/II-44, Beleške sa razgovora pretstavnika SSRNJ i Socijalističke partije Belgije, održanih u Beogradu, 11. i 12. aprila 1956, 3-4.

65 Ibid., 5-8. 
According to Kardelj, the primary focus of resolving current problems in international relations was in the relaxation of relations between the East and West, while socialists' task across the world was "to be active on that line." ${ }^{\prime 6}$ The role of the USSR in world politics was inevitable, so as the Yugoslavs saw it, the attitude of the socialist parties towards Moscow was crucial for the international socialist movement and vice versa. The problem with the international development of socialism, which both sides agreed on, was that the USSR regarded the development of socialism exclusively through communist forces, whereas socialist parties saw the same process through parliamentary democracy. ${ }^{67}$ Such an attitude towards the current position of the USSR was repeated by Tito, who pointed out that Stalin was the problem, and said that the new Soviet leadership was pursuing a different policy that should be acknowledged. ${ }^{68}$ On the other hand, the Belgians were more sceptical about rapid change in the USSR, while they especially harboured doubts about Moscow's good intentions towards the Belgian Socialist Party. ${ }^{69}$ Thus, Paul-Henri Spaak an eminent Belgian Socialist and Minister of Foreign Affairs openly expressed such doubts at this meeting, seeking evidence of democratic processes indicators in the USSR, highlighting that he "he is not as convinced as the Yugoslavs." 70

A special topic of the meeting between Belgian Socialists and Yugoslav Communists was Europe. In the early 1950s, the idea of uniting Europe, i.e., creating stronger alliances between countries, was very topical in Western European political circles, mainly on the economic basis, but also in other spheres, which in some visions implied independence in relation to two opposing blocs. ${ }^{71}$ Belgian Socialists were especially en-

66 Ibid., 22.

67 Ibid., 22-23.

68 AJ, 507/IX, CK SKJ, KMOV, Belgija, 11/II-44, Zabeleška o razgovoru druga Tita sa delegacijom Socijalističke partije Belgije, Brioni, 13. april 1956, 53.

69 AJ, 507/IX, CK SKJ, KMOV, Belgija, 11/II-44, Beleške sa razgovora pretstavnika SSRNJ i Socijalističke partije Belgije, održanih u Beogradu, 11. i 12. aprila 1956, 25.

70 Ibid., 11.

71 The idea of union and independence of (Western) Europe, particularly after WWII, was present among European socialists, but also in the circles of the centre and the right. Numerous prominent political figures in Western Europe worked on this plan in the early 1950s. Thus, various ideas, such as the "United States of Europe," became very popular, and soon some of them began to be implemented, such as the European Coal and Steel Community in 1951 (in 1957, it became the European Economic Community, and in 1992 in today's European Union), or the idea of the European Army, which was not realized or the issue of armaments and the unification of Germany, as one of the central issues in Europe at the time. In this regard, Belgian Socialists and some prominent people from their circles were particularly engaged 
gaged in this regard, particularly some of their eminent individuals, such as Paul-Henri Spaak, then Minister of Foreign Affairs of Belgium. Spaak was a politician strongly inclined to the ideas of a European union and also very engaged in that matter. His political leanings were considered pro-American and anti-Soviet. ${ }^{72}$ In Yugoslavia, he saw a country of geostrategic and political significance, primarily in terms of defence against the USSR and then in the context of European political integration. That is why he personally initiated cooperation with Yugoslavia, especially during his service as Minister of Foreign Affairs of Belgium (1954-1958). That is how his official visit as the Belgian foreign minister took place, from April 7 to $14,^{73}$ which largely coincided with the visit of the PSB delegation, so Spaak, himself a high-ranking official of the Belgian party, participated in the delegation's activities. ${ }^{74}$

As a Belgian official and leader of the Socialist Party, Paul-Henri Spaak spoke about the position of Europe in relation to two blocs and forces, the USSR and the USA in Yugoslavia in April 1956. He spoke of Europe as a "third force" that should profile, expand and strengthen its influence in world politics. He especially emphasized the importance of cooperation between European countries in the field of economic policy. The Federal Secretary of Foreign Affairs of Yugoslavia, Koča Popović, confirmed

in this period. The Yugoslav leadership was mainly reserved about such ideas. See: Никола Мијатов, „Југославија и уједињавање Западне Европе“, Токови историје 2/2016, 177-196; Милетић, Преломна времена, 60-62, 143.

72 Мијатов, „Југославија и уједињавање Западне Европе“, 181.

73 See: AJ, 507/IX, CK SKJ, KMOV, Belgija, 11/II-44, Program službene posete ministra inostranih poslova Belgije g. Henri Spaaka Federativnoj Narodnoj Republici Jugoslaviji; AJ, Fond 836, Kancelarija maršala Jugoslavije (KMJ), I-3-a/10-3, Prijem ministra inostranih poslova Belgije Pol Anri Spaka i delegacije Socijalističke partije Belgije FNRJ, 7-14. 4. 1956; DAMSPRS, PA, 1956, Belgija, f. 7, br. 45303, Zabeleška o razgovoru Koče Popovića i Paul-Henri Spaak-a, 8. 4. 1956.

74 According to documents of Yugoslav diplomatic provenance, Spaak launched the initiative to visit Yugoslavia in mid-1955, and the reason was support for the concept of European integration as the "third force". The Yugoslav diplomats judged Spaak's initiative to be politically useful, both because it could improve relations and because his pro-American attitude, as they believed, could be helpful for "influencing the United States". They also believed the Belgian foreign minister could be "interesting for our operations in relation to the Council of Europe". However, this initiative was not immediately met with a positive attitude in the Yugoslav Secretariat for Foreign Affairs (SIP), so Spaak's visit was postponed until the spring of 1956. See: DAMSPRS, PA, 1955, Belgija, f. 6, br. 43717, Poziv Spaak-u, ministru spoljnih poslova da poseti Jugoslaviju, 22. 9. 1955; DAMSPRS, PA, 1956, Belgija, f. 6, br. 43717, Telegram ambasadi FNRJ u Briselu, 14. 10. 1955; DAMSPRS, PA, 1956, Belgija, f. 6, br. 43717, Telegram ambasadi FNRJ u Briselu, 20. 10. 1955. 
the importance of the economic aspect of the regional countries' union, including Europe, but stressed that Yugoslavia did not intend, in accordance with its independence policy, to join any political organization, including the European Council. Koča Popović made it clear to his counterpart Spaak that Yugoslavia distinguished between technical and economic cooperation and membership in a world's political organization, which Yugoslavs did not want, or "adaptation to existing European organizations" would not be in accordance with its aspiration to "increase and expand cooperation among all countries." Therefore, it was eventually concluded that the issue of Yugoslavia's relations and potential joining the European Council would be postponed until further notice, which was, in fact, a manifestation of Yugoslavia's reserved attitude towards European integrationist political ideas, particularly the intention of Europe to "draw" Yugoslavia in European political relations, both in Europe and in the world. ${ }^{75}$

The relations and cooperation between Yugoslav Communists and Belgian Socialists in the first half of the 1950s could be assessed as positive, and at times openly friendly. The Belgian Socialist Party often supported Yugoslav policy, particularly in the Socialist International, while the positive aspect of this cooperation was reflected directly in the practice of mutual aid, e.g., at the technical level. The divergences were mainly on the issue of European politics and democracy, which did not have much of an impact on the positive balance of cooperation between the two parties in this period.

\section{Summary}

Regardless of the relative geostrategic distance between the two countries, Yugoslav-Belgian relations were friendly in the first half of the 1950s. At that time, a particularly friendly relationship was nurtured with the leading socialist political factor in Belgium, the Belgian Socialist Party (PSB). Cooperation with the Belgian Socialists was initiated in the early 1950s, and the beginning of official cooperation was the visit of a high delegation of the PSB to Yugoslavia (1952), when the ascending line in mutual relations began. Belgian socialists, especially their prominent individuals, supported Yugoslav policy and often openly advocated the causes of Yugoslav communists before Western European socialists. This support

75 See: AJ, 507/IX, СК SКJ, KMOV, Belgija, 11/II-44, Beleške sa razgovora pretstavnika SSRNJ i Socijalističke partije Belgije, održanih u Beogradu, 11. i 12. aprila 1956, 34-45. 
was especially present in influential international forums and organizations such as the Socialist International. In a series of official or unofficial meetings, visits, contacts or individual political ties, a solid foundation was built for friendly relations between the two parties, as well as the two countries, which was one of the important bridges for Yugoslavia's political "breakthrough" in the West. On the other hand, the discrepancies in attitudes came to the fore first in attitudes about parliamentarism and democracy, and then on some foreign policy issues, primarily in views on USSR policy (the common threat of aggression from the East up to 1953 , and then the question of stabilizing relations with Moscow after Stalin's death), in attitudes about problems in Europe, issues of collective security, etc.

\section{Sources and Literature}

- $\quad$ Arhiv Jugoslavije: Fond 507/IX, CK SKJ, Komisija za međunarodne odnose i veze; Fond 142, Socijalistički savez radnog naroda Jugoslavije; Fond 836, Kancelarija maršala Jugoslavije.

- Diplomatski arhiv Ministarstva spoljnih poslova Republike Srbije. Politička arhiva.

- $\quad$ Balkanski pakt 1953/1954, prir. dr Milan Terzić, dr Mihajlo Basara, Nemanja Milošević, Miljan Milkić, Dmitar Tasić, Tatjana Lečić. Beograd: Vojnoistorijski institut, 2005.

- Banac, Ivo. Sa Staljinom protiv Tita. Informbirovski rascjepi u jugoslavenskom komunističkom pokretu. Zagreb: Globus, 1990.

- Bekić, Darko. Jugoslavija u Hladnom ratu. Odnosi sa velikim silama 19491955. Zagreb: Globus, 1988.

- $\quad$ Bogetić, Dragan. Jugoslavija i Zapad 1952-1955. Jugoslovensko približavanje NATO-u. Beograd: Službeni list SRJ, 2000.

- Bogetić, Dragan. Koreni jugoslovenskog opredeljenja za nesvrstanost. Beograd: ISI, 1990.

- $\quad$ Bogetić, Dragan. Nesvrstanost kroz istoriju. Od ideje do pokreta. Beograd: Zavod za užbenike, 2019.

- Bogetić, Dragan. Nova strategija jugoslovenske spoljne politike 1956-1961. Beograd: ISI, 2006.

- $\quad$ Childs, David. The Two Red Flags. European Social Democracy and Soviet Communism since 1945. London - New York: Routledge, 2002.

- Dedijer, Vladimir. Izgubljena bitka Josifa Visarionoviča Staljina. Sarajevo: Svetlost, Prosvjeta, Oslobođenje, 1969.

- Dedijer, Vladimir. Veliki buntovnik Milovan Đilas. Prilozi za biografiju. Beograd: Prosveta, 1991. 
- $\quad$ Dimić, Ljubodrag. Jugoslavija i Hladni rat. Ogledi o spoljnoj politici Josipa Broza Tita (1944-1974). Beograd: Arhipelag, 2014.

- $\quad$ Đilas, Milovan. O agresivnom pritisku vlada sovjetskog bloka protiv Jugoslavije. Beograd: Borba, 1951. (cyrillic)

- $\quad$ Đilas, Milovan. Savremene teme. Beograd: Borba, 1950. (cyrillic)

- $\quad$ Đilas, Milovan. Vlast i pobuna. Beograd: Književne novine, 1991.

- $\quad$ Eley, Geoff. Forging Democracy. The History of the Left in Europe, 1850-2000. New York: Oxford University Press, 2002.

- Imlay, Talbot C. The Practice of Socialist Internationalism. European Socialists and International Politics, 1914-1960. Oxford: Oxford University Press, 2018.

- Jovanović, Jadranka.Jugoslavija u Ujedinjenim nacijama 1945-1953. Beograd: ISI, 1985.

- Jugoslovensko-sovjetski sukob 1948. Zbornik radova sa naučnog skupa, ur. Đoko Tripković. Beograd: ISI, 1999.

- Kemseke, Peter Van. Towards an Era of Development. The Globalization of Socialism and Christian Democracy 1945-1965. Leuven: Leuven University Press, 2006.

- $\quad$ Laker, Volter. Istorija Evrope 1945-1992. Beograd: CLIO, 1999. (cyrillic)

- Laković, Ivan. Zapadna vojna pomoć Jugoslaviji 1951-1958. Podgorica: Istorijski institut Crne Gore, 2006.

- Mijatov, Nikola. Milovan Đilas i evropski socijalisti 1950-1958. Beograd: ISI, 2019.

- Mijatov, Nikola.,JugoslavijaiujedinjavanjeZapadne Evrope1950-1958“'Tokovi istorije 2/2016, 177-196. (cyrillic) doi: 10.31212/tokovi.2016.2.mij.177-196

- Miletić,Aleksandar V.,,MilovanĐilas i francuski socijalisti1950-1954“. Tokovi istorije1/2020,155-174.(cyrillic) doi: 1031212/tokovi.2020.1.mil.155-174

- Miletić, Aleksandar V. „Politička delatnost Milovana Đilasa (1944-1954)“. Doktorska disertacija, Univerzitet u Beogradu, Filozofski fakultet, Odeljenje za istoriju, 2017. (cyrillic)

- $\quad$ Miletić, Aleksandar V. Prelomna vremena. Milovan Đilas i zapadnoevropska socijalistička i socijaldemokratska levica 1950-1954. Beograd: INIS, 2019.

- Miletić, Aleksandar V. „Prijem delegacije britanskih laburista kod maršala Tita u okviru njihove prve posete Jugoslaviji, 1950. godine”. Tokovi istorije 1/2011,137-164. (cyrillic)

- $\quad$ Miletić, Aleksandar V. Titov emisar Milovan Đilas. Diplomatsko-pregovaračke i spoljnopolitičke aktivnosti (1943-1953). Beograd: INIS, 2021. (cyrillic)

- Miletić, Aleksandar V. "The Relationships between Yugoslav Communists and Scandinavian Socialists in the Light of Yugoslav Sources (1950-1953)". Acta Histriae 1/2019, 75-87.

- Miletić, Aleksandar V. “'Unrelized Nordic Dream'. Milovan Đilas and the Scandinavian Socialists”. Tokovi istorije 3/2015, 89-106. doi: 10.31212/tokovi.2015.3.mil.89-106 
- $\quad$ Padgett, Stephen, William E. Paterson. A History of Social Democracy in Postwar Europe. New York: Longman, 1991.

- $\quad$ Sassoon, Donald. One Hundred Years of Socialism. The West European Left in the Twentieth Century. London - New York: I. B. Tauris, 2010.

- S Štrbac, Čedomir. „Britanski laburisti u Jugoslaviji 1950“. Međunarodni problemi 4/1987, 543-551.

- $\quad$ Štrbac, Čedomir. Jugoslavija i odnosi između socijalističkih zemalja. Sukob KPJ i Informbiroa. Beograd: Prosveta, 1984.

- Štrbac, Čedomir. Svedočanstva o 1948. Beograd: Zavod za udžbenike i nastavna sredstva, 1989.

- $\quad$ Velike sile i male države u hladnom ratu 1945-1955. Slučaj Jugoslavije, ur. Ljubodrag Dimić. Beograd: Filozofski fakultet, Arhiv SCG, INIS, 2008.

- Zbornik radova sa međunarodnog okruglog stola: Tito-Staljin, ur. Miladin Milošević. Beograd: Arhiv SCG, 2007.

- Životić, Aleksandar. Vašingtonska konferencija 1951. Beograd: Zavod za udžbenike, INIS, 2015. (cyrillic) 


\title{
Резиме
}

Александар В. Милетић

\section{Југословенски комунисти и белгијски социјалисти 1950-1955.}

\begin{abstract}
АпстрАкт: Овај рад обрађује једну помало заборављену тему из сфере југословенске спољне политике у Хладном рату: однос југословенских комуниста и белгијских социјалиста на почетку 50-их година 20. века. Истраживање је обављено у највећој мери на основу необјављених архивских извора југословенске провенијенције, као и одговарајуће научно-историографске и друге стручне литератуpe.

КљУчнЕ РЕчИ: југословенски комунисти, белгијски социјалисти, Хладни рат, Југославија, Белгија
\end{abstract}

Југословенско-белгијски односи су у првој половини 50-их година били на пријатељском нивоу, без обзира на релативну геостратешку удаљеност две земље. Тако је исти однос негован и са водећим социјалистичким политичким чиниоцем у Белгији - Белгијском социјалистичком партијом (БСП). Сарадња са белгијским социјалистима је покренута почетком 50-их, када и са већим бројем других социјалистичких партија и појединаца у Западној Европи. Почетком званичне сарадње југословенских комуниста са белгијском партијом сматра се посета високе делегације БСП-а Југославији (1952), када почиње и узлазна линија у међусобним односима. Белгијски социјалисти, посебно њихови угледни појединци, подржавали су југословенску политику и често отворено заступали југословенске комунисте пред другим западноевропским социјалистичким партијама, нарочито у утицајним форумима и организацијама попут Социјалистичке интернационале. У низу званичних или незваничних састанака, посета, контаката и индивидуалних политичких веза, током овог периода је изграђена солидна основа за пријатељске односе две партије, па и две земље, што је Југославији било важно као један од мостова за политички „пробој“ на Западу. С друге стране, мимоилажења у ставовима долазила су до изражаја најпре по питању односа 
према парламентаризму и демократији, а потом и по неким питањима у спољнополитичкој сфери, пре свега у вези са политиком СССР-а (заједничка опасност од агресије са Истока до 1953, а затим и питање стабилизације односа са Москвом после Стаљинове смрти), проблемима Европе, питањем колективне безбедности и сл. 